\title{
Anesthetic management for pediatric strabismus surgery: Continuing Professional Development
}

\author{
Amy Rodgers, MD $\cdot$ Robin G. Cox, MBBS
}

Received: 11 January 2010/Accepted: 5 March 2010/Published online: 15 April 2010

(c) Canadian Anesthesiologists' Society 2010

\begin{abstract}
Purpose Strabismus surgery is one of the most common pediatric ophthalmic procedures. The purpose of this continuing professional development module is to update physicians on the anesthetic considerations of pediatric patients undergoing strabismus surgery.

Principal findings The preoperative assessment is important, as patients undergoing strabismus surgery may have an associated neuromuscular disorder, congenital syndrome, or cardiac disease. Malignant hyperthermia is no longer considered as being an issue associated with strabismus. The laryngeal mask airway is used frequently and has been shown as being associated with a low incidence of complications in strabismus surgery. The anesthesia technique can be adapted to decrease the incidence of the oculocardiac reflex and the oculorespiratory reflex, and the use of anticholinergic prophylaxis remains debatable. Since patients are at high risk for postoperative nausea and vomiting $(P O N V)$, combination anti-emetic therapy is recommended using dexamethasone and ondansetron. Metoclopramide was not found to provide additional benefit when combined with other anti-emetics. Droperidol is effective, but there remains a black box warning for dysrhythmias. Effective analgesics in this patient population include acetaminophen, nonsteroidal anti-inflammatory
\end{abstract}

A. Rodgers, MD - R. G. Cox, MBBS

Department of Anesthesia, University of Calgary,

Calgary, AB, Canada

A. Rodgers, MD $(\bowtie) \cdot$ R. G. Cox, MBBS

Division of Pediatric Anesthesia, Alberta Children's Hospital,

2888 Shaganappi Trail NW, Calgary, AB T3B 6A8, Canada

e-mail: aerodgers@hotmail.com drugs, peribulbar blocks, and subtenon blocks. Topical tetracaine drops have demonstrated mixed results, and topical nonsteroidal anti-inflammatory drops were found not to be effective. The use of opioids should be minimized due to the increased incidence of PONV.

Conclusions To provide optimal care for the pediatric patient undergoing strabismus surgery, it is important to understand the unique anesthetic considerations for strabismus surgery and to appreciate how each decision regarding the anesthetic technique can alter these considerations.

Objectives of this continuing professional development (CPD) module

Upon completion of this CPD module, the reader will be able to:

1 Perform a thorough preoperative assessment with an emphasis on the co-existing diseases and syndromes with ocular manifestations;

2. Evaluate the possibility of an increased incidence of masseter muscle spasm or malignant hyperthermia in this patient group;

3. Detail an anesthetic plan for strabismus surgery, including airway management and choice of anesthetic agents;

4. Understand the mechanism of the oculocardiac and the oculorespiratory reflex and recognize the associated risk factors and treatment;

5. Determine the analgesia options for strabismus surgery; and

6. Plan evidence-based anti-emetic prophylaxis for strabismus surgery. 


\section{Summary review}

Strabismus surgery is the most common pediatric ophthalmic procedure. ${ }^{1,2}$ The purpose of this continuing professional development module is to review the unique anesthetic issues facing a patient presenting for strabismus surgery. It is important to be aware of specific issues, such as the association with specific syndromes and diseases, the occurrence of the oculocardiac reflex, and the increased risk of postoperative nausea and vomiting. The effects of varying anesthetic techniques on oculocardiac reflex (OCR) and the management of postoperative nausea and vomiting (PONV) will also be addressed.

\section{Strabismus and strabismus surgery}

Strabismus is an ocular misalignment that causes loss of binocular vision and amblyopia (vision loss in a structurally normal eye) ${ }^{3}$ It has a $2-7 \%$ prevalence in children, ${ }^{2-5}$ and presents typically from the ages of one to four. ${ }^{6}$ Neonatal misalignment resolves mostly by the age of three months, and after that it is considered abnormal. ${ }^{6}$ Most cases that present in late childhood or in adults are typically the recurrence of partially treated strabismus; however, in the case of a new presentation, a neurological examination should be performed. ${ }^{6}$ The goals of surgery are to restore the alignment of the eyes to maintain visual acuity (no amblyopia), to provide good cosmetic correction (orthotropia), to improve depth perception (stereopsis), and to eliminate double vision. ${ }^{4-6}$ Visual maturation occurs by five years of age, so it is important to repair the strabismus in early childhood. ${ }^{6}$

\section{Procedure}

The surgical procedure involves making an incision through the conjunctiva and tenon fascia, then locating the muscles and exposing their insertion points. Next, the surgeon repositions the extraocular muscles, usually by one of the following three movements: 1) Recession-weakening a muscle by moving its insertion point more posterior; 2) Resection-strengthening a muscle by eliminating a piece of the muscle; or 3) Transposition-altering the action of the muscle by reattaching the muscle at a new location. ${ }^{2,4}$ It is difficult to gauge the extent of correction necessary; hence, some surgeries result in an overcorrection or undercorrection requiring additional surgery. ${ }^{6}$ Complications related to the surgery are rare but include infection, slippage of the operated muscle, light sensitivity, blurred vision from medications or tearing, and severe vision loss from intraocular infection or retinal detachment from globe perforation. ${ }^{2,4,6}$

\section{Forced duction testing}

The ophthalmologists may test the range of motion of the extraocular muscles to help distinguish between paralytic and mechanical restriction. The results of this test may alter the surgical technique. Many anesthesia textbooks maintain that surgeons may request non-depolarizing muscle relaxants to remove interference with the test; however, this option is not common in clinical practice. Succinylcholine should be avoided as it causes prolonged depolarization and muscle contraction (approximately $20 \mathrm{~min}$ ) of the extraocular muscles, which may lead to false conclusions in the forced duction test. ${ }^{2,5}$

\section{Associated diseases}

Most children presenting for strabismus surgery are healthy, and about half of strabismus patients will have a positive family history of strabismus. ${ }^{2}$ When it occurs in the absence of neurological abnormalities, the exact cause of strabismus is unknown. Associated neurological abnormalities include cerebral palsy, myelomeningocele, hydrocephalus, craniofacial syndromes, neurofibromatosis, seizure disorders, or structural abnormalities of the eye. ${ }^{2,5,6}$ There are nonspecific risk factors for strabismus, such as attention-deficit hyperactivity disorder, maternal smoking, and premature birth. ${ }^{2}$ In the preanesthetic evaluation, it is important to consider diseases or syndromes (Table 1) associated with strabismus, such as congenital heart disease or cardiomyopathy, as each has its specific anesthetic considerations that are important to review. ${ }^{7,8}$

\section{Malignant hyperthermia/masseter muscle spasm}

The suggestion that there is an increased incidence of malignant hyperthermia (MH) and masseter muscle spasm (MMS) in strabismus patients has been controversial. In the past, an association between $\mathrm{MH}$ and patients undergoing strabismus surgery has been reported, as patients with $\mathrm{MH}$ were noted as having a higher incidence of musculoskeletal abnormalities, such as strabismus or ptosis. ${ }^{9}$ Subsequently, a review of more than 2,500 patients tested for MH susceptibility was unable to show an association with strabismus surgery patients. ${ }^{9}$ As stated in an editorial by Girard and Litman, "pediatric anesthesiologists may remember a time when strabismus was considered a predisposing risk factor for $\mathrm{MH}$ susceptibility. This is no longer the case, of course; children with strabismus are now routinely anesthetized with inhalational anesthetics without any apparent increase in the incidence of MH". ${ }^{10}$ In addition, older studies described a fourfold incidence of MMS in pediatric strabismus patients compared with nonstrabismus patients after a halothane induction followed by 
Table 1 Congenital syndromes and chromosomal abnormalities associated with strabismus

\begin{tabular}{|c|c|}
\hline Syndrome & Anesthetic considerations \\
\hline Apert's syndrome & Possible difficult intubation, possible choanal stenosis, cervical spine fusion, CHD (10\%) \\
\hline Cri du chat syndrome & Micrognathia, possible difficult intubation, hypotonia, prone to hypothermia, CHD (33\%) \\
\hline Crouzon's disease & Possible difficult intubation, possible elevated intracranial pressure \\
\hline Down syndrome & Trisomy 21, airway obstruction, atlantoaxial instability, CHD (50\%) \\
\hline Goldenhar's syndrome & $\begin{array}{l}\text { Hemifacial microsomia, possible cervical spine abnormalities, possible difficult mask and intubation, } \\
\text { rare CHD, and hydrocephalus }\end{array}$ \\
\hline Homocystinuria & $\begin{array}{l}\text { Marfanoid habitus with kyphoscoliosis and sternal deformity, prone to thromboembolic complications } \\
\text { and hypoglycemia }\end{array}$ \\
\hline Marfan syndrome & Aortic or pulmonary artery dilation, aortic and mitral valve disease, pectus excavatum, risk for pneumothorax \\
\hline Moebius sequence & Possible difficult intubation, micrognathia, copius secretions, possible cervical spine anomalies \\
\hline Myotonic dystrophy & $\begin{array}{l}\text { Prone to myotonic contractions, succinylcholine-associated contractions and hyperkalemia, frequent } \\
\text { cardiac conduction abnormalities, sensitive to central nervous system depressants }\end{array}$ \\
\hline Stickler syndrome & Possible difficult intubation, micrognathia, mitral valve prolapse, marfanoid habitus, scoliosis, kyphosis \\
\hline Turner syndrome & Possible difficult intubation and intravenous access, CHD \\
\hline
\end{tabular}

Excerpts of table reprinted from Smith's Anesthesia for Infants and Children, $7^{\text {th }}$ ed. Motoyamo EK, Davis PJ (Eds). Chapter 22: Anesthesia for pediatric ophthalmic surgery, page 774, Table 22-1. Copyright (2006), with permission from Elsevier. CHD = congenital heart disease

a single dose of succinylcholine. ${ }^{5}$ Conflicting results were obtained in another study in healthy non-strabismus and strabismus patients. That study demonstrated that succinylcholine under halothane anesthesia caused a similar increase in jaw tension and degree of neuromuscular blockade; however, there were only eight subjects in each group. ${ }^{11}$ Unfortunately, there is no objective measure of MMS and it can be difficult to diagnose. The "jaws of steel" represents a clinical state during which the mandible cannot be displaced from the maxilla to facilitate insertion of any airway. Some suspect that certain cases of MMS may be a normal response to succinylcholine. ${ }^{9,10}$ In summary, it seems the association between strabismus and $\mathrm{MH}$ is no longer an issue; however, if MMS is suspected in a patient, it is important to recognize that this patient may be susceptible to $\mathrm{MH}^{9,12}$ The importance of a detailed anesthetic family history is emphasized.

\section{Oculocardiac reflex}

\section{Definition}

The OCR is usually defined as a $20 \%$ decrease in heart rate (HR) from baseline, dysrhythmias, or sinoatrial arrest associated with ocular muscle traction. ${ }^{13-17}$ Other studies have defined this reflex to include a 10-30\% decrease in HR from baseline. ${ }^{18-20}$ It is a trigeminal-vagal reflex that can lead to a variety of arrhythmias, including sinus bradycardia, junctional rhythm, atrial ectopic, atrioventricular block, ventricular bigeminy, wandering pacemaker, multifocal premature ventricular contractions, idioventricular rhythm, ventricular tachycardia, or asystole. ${ }^{2,5}$ The incidence of OCR during strabismus surgery varies from 14-90\% depending on administration of an anticholinergic, the choice of anesthetic agents, and the definition of OCR used. $5,14,15,18,19,21,22$

\section{Triggers}

In addition to traction on the extraocular muscles, triggers of OCR include pressure on orbital structures or on the tissue remaining in the orbital apex after enucleation, ocular trauma, or an increase in intraorbital pressure from an injection or hematoma. ${ }^{5,7,18}$ It is thought that OCR is seen more often with traction of the medial rectus; ${ }^{14,23}$ however, Blanc et al. ${ }^{24}$ were unable to show that the medial rectus triggers OCR more often than the other extraocular muscles if the same type of stimulus is used. The OCR is a graded phenomenon where bradycardia becomes more severe and occurs more quickly if the tension is abrupt and sustained. ${ }^{23}$ The response generally disappears as the stimulation is discontinued. This phenomenon is called vagal escape or OCR fatigue. It is a physiologic defense mechanism where the HR response diminishes after sustained or repeated extraocular muscle manipulation.

\section{Oculorespiratory reflex}

The oculorespiratory reflex has the same triggers as OCR, except it results in a reduction in tidal volume and respiratory rate. ${ }^{13}$ The afferent pathways are the same as in OCR, but they are directed to the respiratory control area of the brainstem instead, and the efferent fibres travel along the phrenic nerve and other nerves involved in respiration. The oculorespiratory reflex may produce hypercapnia and hypoxemia that can increase the incidence of OCR. 


\section{Prevention of OCR}

The following are basic principles for preventing OCR: the surgeon must give advance notice before manipulating the extraocular muscles, surgical manipulation must be gentle, depth of anesthesia must be adequate, and hypoxia and hypercarbia must be avoided. ${ }^{2}$ Administering atropine or glycopyrrolate decreases the incidence of OCR; $;^{2,5,23,25}$ however, systematic prophylactic anticholinergic administration remained controversial in the past because it was associated with ventricular arrhythmias. Also, in most of these reports, the patients were receiving halothane anesthesia, which also increased the incidence of arrhythmias. To avoid interference with the study results, anticholinergic medications were not used in most recent studies evaluating the effects of various anesthetic medications on the incidence of OCR. Despite this, the HR returned to baseline with release of the extraocular muscle in the majority of cases with minimal intervention. These studies demonstrated that the incidence of OCR is affected significantly by the type of anesthetic administered. It has also been suggested that prophylactic anticholinergics be used to reduce the rate of PONV by decreasing the incidence of OCR; however, this option has not been demonstrated in pediatric strabismus. ${ }^{25}$

\section{Treatment}

The initial response to OCR is to ask the surgeon to stop surgical manipulation immediately, to assess the patient's ventilatory status to rule out hypercarbia or hypoxia, and then to evaluate the depth of anesthesia. ${ }^{5,7}$ As a rule, the HR returns to baseline fairly quickly when the stimulation is discontinued. ${ }^{2}$ Atropine should be administered if hemodynamic instability or arrhythmias occur as a result of bradycardia.

\section{Postoperative nausea and vomiting}

The occurrence of PONV after strabismus surgery remains an important problem. The incidence of PONV without prophylaxis varies from $37-90 \%, 2,26,27$ and untreated PONV can result in complications, such as dehydration, electrolyte imbalance, ${ }^{7}$ subconjunctival hemorrhage, loosening of surgical attachments, delayed discharge, and unplanned admissions. ${ }^{2}$ In addition, it may decrease satisfaction and increase the use of resources. ${ }^{26,28}$

Major risk factors for postoperative vomiting (POV) in pediatric surgery include the type of surgery (e.g., strabismus surgery, tonsillectomy), age $>$ three years, duration of anesthesia $>30 \mathrm{~min}$, and a personal or family history of POV, PONV, or motion sickness. ${ }^{7,26}$ In addition, there are risk factors specific to strabismus surgery that increase the incidence of POV. These include the oculoemetic reflex-a centrally mediated reflex related to eye muscle manipulation, ${ }^{7,27}$ an alteration in visual perception postoperatively, ${ }^{7}$ a positive $\mathrm{OCR},{ }^{7}$ the surgical technique, ${ }^{29}$ and the number of repaired eye muscles. ${ }^{26,30}$ The surgical technique, myopexy, ${ }^{29}$ where posterior fixation of the muscle via a suture results in a more sustained stimulation, is associated with an increased incidence of POV.

\section{Anti-emetics}

Most of the evidence on anti-emetic prophylaxis in children is limited to POV as an endpoint, as it is difficult to diagnose nausea in children. ${ }^{26}$ Also, it is difficult to compare studies as there are many different anesthetic techniques, medications, and end points chosen. The majority of the literature focuses on anti-emetic prophylaxis rather than treatment in pediatric strabismus patients. Most of the anti-emetic drugs studied in the following section are administered intravenously. Dimenhydrinate $0.5 \mathrm{mg} \cdot \mathrm{kg}^{-1}$ was shown to be more effective than placebo (incidence of POV $10 \% \mathrm{vs}$ $38 \%$, respectively); however, the dose-response curves, optimal time of administration, and benefit of repetitive doses remain unclear, and it is unclear whether dimenhydrinate causes sedation and delay to discharge. ${ }^{26}$ In 1995, a systematic review with numbers needed to treat (NNT) of four and 2.5 demonstrated that doses of metoclopramide 0.15 and $0.25 \mathrm{mg} \cdot \mathrm{kg}^{-1}$, respectively, on their own were more effective than placebo only to prevent early vomiting up to six hours. ${ }^{31}$ The same review with a NNT of four patients concluded that droperidol $75 \mu \mathrm{g} \cdot \mathrm{kg}^{-1}$ is the most effective dose to avoid one episode of vomiting. ${ }^{31}$ When postoperative sedation in ambulatory surgical patients became an issue, the use of droperidol decreased initially, and its use decreased even more in 2001 when a controversial black box warning was issued by the Food and Drug Administration that droperidol in high doses causes QT prolongation. ${ }^{26}$ When comparing anti-emetics, ondansetron and droperidol were more effective than metoclopramide and placebo in reducing predischarge PONV (incidence of $5 \%, 5 \%, 32 \%$, and $25 \%$ respectively); however, there was no difference between the groups when evaluating postdischarge PONV (incidence of 25\%, 25\%, 20\%, and $25 \%$, respectively). ${ }^{26}$ Dexamethasone and ondansetron are antiemetics used commonly in pediatric strabismus surgery. In dose finding studies, dexamethasone $50 \mu \mathrm{g} \cdot \mathrm{kg}^{-1}$ was found to be just as effective as higher doses, such as $250 \mu \mathrm{g} \cdot \mathrm{kg}^{-1}$ (incidence of PONV $42.9 \%$ and $40.9 \%$, respectively; placebo $92.9 \%),{ }^{32}$ and dexamethasone $250 \mu \mathrm{g} \cdot \mathrm{kg}^{-1}$ was just as effective as $1 \mathrm{mg} \cdot \mathrm{kg}^{-1}$ (incidence of POV $26 \%$ and $21 \%$, respectively; placebo $66 \%){ }^{33}$ Ondansetron was effective at doses ranging from $0.05-0.2 \mathrm{mg} \cdot \mathrm{kg}^{-1}$ and had minimal side effects. $2,26,27,31,34$ When evaluating the timing of 
administration of ondansetron, $100 \mu \mathrm{g} \cdot \mathrm{kg}^{-1}$ was found to be just as effective whether given before or after ocular muscle manipulation (incidence of POV $35 \%$ vs 33\%, respectively) $;{ }^{26}$ however, administering a dose prophylactically rather than treating symptoms shortened the time to discharge and improved overall satisfaction at a lower cost. ${ }^{26}$ Compared with using propofol for induction and maintenance of anesthesia, ondansetron $150 \mu \mathrm{g} \cdot \mathrm{kg}^{-1}$ (with halothane, nitrous oxide, and oxygen) was found to be equally effective at reducing POV in pediatric strabismus patients (incidence of POV $26 \%$ vs $27 \%$, respectively). ${ }^{26}$ Other serotonin antagonists (granisetron, ramosetron) were studied with positive results but did not offer significant advantages over ondansetron. ${ }^{26}$ Finally, acupressure to the P6 acupuncture point, a less common form of anti-emetic treatment, was found to be effective. ${ }^{7,26,35}$

\section{Combination anti-emetic therapy}

It is recommended that patients at high risk of nausea and vomiting receive combination anti-emetic therapy from different drug classes. ${ }^{7,26}$ Multiple studies have demonstrated that the combination of ondansetron and dexamethasone is more effective than either ondansetron or dexamethasone alone ${ }^{26,36-38}$ (Table 2). In addition, the combination of droperidol and either ondansetron or granisetron is more effective in reducing POV than either drug administered alone. ${ }^{26}$ However, when metoclopramide was added to either droperidol or ondansetron, it was not more effective at reducing anti-emetic symptoms than either agent alone. ${ }^{26}$

\section{Anesthetic technique}

The incidences of PONV and OCR with strabismus surgery are affected by many factors, including the chosen anesthetic technique (Table 3).

\section{Premedication}

If midazolam is used as a premedication, there may be some anti-emetic benefit. ${ }^{39}$ Other benzodiazepines, such as lorazepam and diazepam, have shown to decrease POV in strabismus patients, ${ }^{2,26}$ whereas the use of oral clonidine 2-4 $\mu \mathrm{g} \cdot \mathrm{kg}^{-1}$ as premedication has shown mixed results. ${ }^{7,26}$

\section{Airway}

Strabismus surgery in pediatric patients is performed under a general anesthetic in a supine position. In the past, an endotracheal tube was used routinely to control the airway. The laryngeal mask airway (LMA ${ }^{\mathrm{TM}}$ ) has since increased in popularity. A survey completed in the UK in 1999 showed that $60 \%$ of anesthesiologists used an $\mathrm{LMA}^{\mathrm{TM}}$ in children undergoing strabismus surgery. ${ }^{1}$ A prospective audit of 94 patients undergoing ophthalmic surgery (mainly strabismus surgery) under LMA ${ }^{\mathrm{TM}}$ found a low incidence of complications. ${ }^{40}$

\section{Ventilation}

Spontaneous or controlled ventilation may be used while being aware that hypercarbia can increase the incidence of OCR. ${ }^{24}$ One study investigated the effect of inspired oxygen concentration on the incidence of PONV. Treshan et al. evaluated the difference between using an inspired oxygen fraction of 0.3 with air, an inspired oxygen fraction of 0.8 with air, or an inspired oxygen fraction of 0.3 with air and a dose of ondansetron $75 \mu \mathrm{g} \cdot \mathrm{kg}^{-1}$. They found no statistically significant difference between the groups despite the hypothesis that an increased oxygen fraction intraoperatively decreases PONV. ${ }^{41}$ The effect of nitrous oxide on PONV has been controversial. Studies in adults have shown that eliminating nitrous oxide decreases postoperative emesis; however, studies in children have not shown the same effect, including one performed specifically in strabismus patients. ${ }^{26,30}$

\section{Volatile agents}

With any anesthetic technique, the depth of anesthesia is important. It was demonstrated during sevoflurane anesthesia that bispectral index (BIS) values $>60$ were associated with a higher incidence of OCR compared with
Table 2 Combination antiemetic therapy: ondansetron and dexamethasone

$\mathrm{POV}=$ postoperative vomiting

\begin{tabular}{|c|c|c|}
\hline Author & Drugs & $\begin{array}{l}\text { Incidence } \\
\text { of POV }(24 \mathrm{hr})\end{array}$ \\
\hline \multirow[t]{2}{*}{ Splinter et $a l^{36}$} & $\circ$ Ondansetron $150 \mu \mathrm{g} \cdot \mathrm{kg}^{-1}$ & $28 \%$ \\
\hline & $\circ$ Ondansetron $50 \mu \mathrm{g} \cdot \mathrm{kg}^{-1}+$ Dexamethasone $150 \mu \mathrm{g} \cdot \mathrm{kg}^{-1}$ & $9 \%$ \\
\hline \multirow[t]{2}{*}{ Splinter ${ }^{37}$} & ○ Dexamethasone $150 \mu \mathrm{g} \cdot \mathrm{kg}^{-1}$ & $23 \%$ \\
\hline & ○ Dexamethasone $150 \mu \mathrm{g} \cdot \mathrm{kg}^{-1}+$ Ondansetron $50 \mu \mathrm{g} \cdot \mathrm{kg}^{-1}$ & $5 \%$ \\
\hline \multirow[t]{3}{*}{ Bhardwaj et al. ${ }^{38}$} & $\circ$ Placebo & $64.5 \%$ \\
\hline & $\circ$ Ondansetron $150 \mu \mathrm{g} \cdot \mathrm{kg}^{-1}$ & $33.3 \%$ \\
\hline & $\circ$ Ondansetron $150 \mu \mathrm{g} \cdot \mathrm{kg}^{-1}+$ Dexamethasone $200 \mu \mathrm{g} \cdot \mathrm{kg}^{-1}$ & $10 \%$ \\
\hline
\end{tabular}


Table 3 Factors affecting the incidence of the oculocardiac reflex

\begin{tabular}{lll}
\hline Increase & Decrease & No effect \\
\hline Propofol $^{2,15,18,22,26,31}$ & Anticholinergics $^{2,5,23,25}$ & Sevoflurane = desflurane \\
Light anesthesia $^{20}$ & Ketamine $^{14,18}$ & Spontaneous ventilation \\
Hypercarbia $^{24}$ & Midazolam $^{14}$ & Controlled ventilation \\
Hypoxia $^{24}$ & Rocuronium $^{19}$ & \\
Traction on extraocular muscles $^{23,24}$ & & \\
$\begin{array}{l}\text { Stimulation of orbital structures } \\
\text { S,17,18 }\end{array}$ & \\
Halothane $>$ sevoflurane & \\
Remifentanil $>$ sevoflurane, Desflurane & \\
\hline
\end{tabular}

BIS values of $40 .^{20}$ Halothane is more likely to cause bradycardia, dysrhythmias, and ventilatory disturbances than sevoflurane, ${ }^{13}$ whereas there is no difference between sevoflurane and desflurane and their effects on OCR. ${ }^{17}$

\section{Propofol}

Propofol infusion for maintenance of anesthesia decreases POV. ${ }^{2,26,31}$ However, it does not reduce POV if used instead of thiopental for induction only followed by isoflurane for maintenance in both groups. ${ }^{42}$ Despite propofol's advantage of decreasing POV in pediatric strabismus patients, unfortunately, it causes an increased incidence of OCR compared with other anesthetics. ${ }^{2,15,18,22,26,31}$

\section{Ketamine}

Hahnenkamp et al. ${ }^{18}$ compared four anesthetic techniques and their effect on OCR. The groups included: propofol and alfentantil infusions, ketamine and midazolam infusions, sevoflurane, or halothane. The ketamine and midazolam group experienced the least amount of hemodynamic changes due to OCR. Also, a further study evaluating ketamine demonstrated that a single bolus of ketamine 1 or $2 \mathrm{mg} \cdot \mathrm{kg}^{-1}$ for induction lowered the incidence of OCR when compared with a propofol and sevoflurane combination. $^{14}$ A proposed mechanism may be the increased sympathetic tone associated with ketamine that counteracts parasympathetic stimulation of the OCR.

\section{Muscle relaxants}

Muscle relaxants were used more commonly in strabismus patients when tracheal intubation was the primary method of securing the airway. A study comparing older muscle relaxants suggested that pancuronium decreases the incidence of bradycardia or arrhythmias compared with atracurium, vecuronium, or tubocurarine. More recent studies evaluating rocuronium showed that it decreased the frequency of OCR but not POV; however, there was no mention of whether reversal agents were used. ${ }^{19}$
Fluids

To maintain preoperative hydration, it is recommended to allow the intake of clear fluids until two to three hours preoperatively and then to hydrate liberally intraoperatively with intravenous crystalloid to decrease PONV. ${ }^{5,27}$ Furthermore, a recent study concluded that an intraoperative intravenous lactated Ringers' solution at $30 \mathrm{~mL} \cdot \mathrm{kg}^{-1} \cdot \mathrm{hr}^{-1}$ reduces $\mathrm{PONV}$ in strabismus patients better than a solution at $10 \mathrm{~mL} \cdot \mathrm{kg}^{-1} \cdot \mathrm{hr}^{-1} .43$

\section{Analgesia}

Optimal postoperative analgesia is essential because it may contribute to PONV, emotional distress, and delays in discharge if untreated. ${ }^{27}$ In 2008, the Association of Paediatric Anaesthetists of Great Britain and Ireland published guidelines for analgesia for certain procedures, including recommendations for strabismus surgery. ${ }^{44}$ There were three grade $\mathrm{B}$ recommendations:

1. Intraoperative local anesthetic blocks (subtenon or peribulbar) reduce PONV and may improve perioperative analgesia in comparison with intravenous opioids.

2. Topical nonsteroidal anti-inflammatory drugs (NSAIDs) do not improve pain scores or postoperative analgesic requirements when compared with topical local anesthetics or placebo.

3. Intraoperative opioid and NSAIDs provide similar postoperative analgesia, but opioid use is associated with increased PONV.

\section{Opioids}

Ideally, the use of opioids should be minimized by administering acetaminophen and NSAIDs. ${ }^{2}$ A study comparing the effect on POV of fentanyl, meperidine, and peribulbar block, in combination with a propofol infusion, concluded that the highest incidence of POV was found in the meperidine group; the lowest was found in the peribulbar block, and 
fentanyl fell inbetween. ${ }^{45}$ Other studies have shown that fentanyl increases PONV after strabismus surgery; ${ }^{2}$ however, a propofol and sufentanil technique demonstrated less POV compared with a propofol and isoflurane technique. ${ }^{26}$ Remifentanil was shown to enhance the degree of bradycardia due to OCR compared with sevoflurane and desflurane. ${ }^{15,16}$ When examining the effects of remifentanil compared with fentanyl, there was no difference with respect to the incidence of POV, and, as expected, the patients who received remifentanil had higher pain scores. ${ }^{7,26}$

Topical analgesics

The success of topical tetracaine was demonstrated in two separate studies ${ }^{46,47}$ however, two other studies did not show a benefit. ${ }^{48,49}$ There is evidence of an association between topical diclofenac ${ }^{50}$ and excellent analgesia with a low incidence of PONV; however, this benefit has not been demonstrated with ketorolac. ${ }^{49}$

Blocks

Regional blocks tend to be performed more often in the adult population, as the procedure is completed typically under intravenous sedation. All blocks can be associated with complications, so they tend to be avoided in children who are routinely under a general anesthetic.

\section{Conclusion}

Strabismus surgery is the most common pediatric ophthalmic procedure. Although malignant hyperthermia is no longer a concern in the care of these patients, OCR and PONV continue to be important factors to consider in every decision of the anesthetic technique. An understanding of the unique anesthetic considerations is important to provide optimal care.

\section{Clinical case}

A two-year-old male presents to the operating room of the children's hospital for repair of strabismus of his left eye. $\mathrm{He}$ is not taking medication and he has no allergies. This is his first anesthetic, and there is no family history of reactions to anesthesia. You are the consulting anesthesiologist handling the case.

Instructions for completing the continuing professional development (CPD) module

(1) Read the current article and the references indicated in bold.
(2) Go to: https://www.cpass2.umontreal.ca/selfassessment program/ and select the current module (Anesthetic management for pediatric strabismus surgery: Continuing Professional Development).

(3) Answer the multiple choice questions regarding the case scenario.

(4) Once you have entered all of your answers, you will have access to experts' explanations for all the possible choices.

(5) Participants may claim up to four hours of CPD, for a total of eight credits under Section 3 of the CPD program of the Royal College of Physicians and Surgeons of Canada.

\section{Prise en charge de l'anesthésie pour une chirurgie du strabisme chez l'enfant}

\section{Résumé}

Objectif La chirurgie du strabisme est l'une des interventions ophtalmiques les plus fréquemment réalisées chez l'enfant. L'objectif de ce module de développement professionnel continu est d'informer les médecins des mises à jour concernant les considérations anesthésiques chez les enfants devant subir une chirurgie pour strabisme. Constatations principales L'évaluation préopératoire est importante; en effet, les patients subissant une chirurgie du strabisme pourraient souffrir d'une maladie neuromusculaire, d'un syndrome congénital ou d'une maladie cardiaque, souvent associés au strabisme. L'hyperthermie maligne n'est plus considérée comme un problème associé au strabisme. Le masque laryngé est fréquemment utilisé et il a été démontré qu'il était associé à une faible incidence de complications dans les chirurgies du strabisme. La technique d'anesthésie peut être adaptée afin de réduire l'incidence des réflexes oculocardiaque et oculorespiratoire, et l'utilisation d'anticholinergiques en prophylaxie demeure discutable. Comme cette population de patients présente un risque plus élevé de manifester des nausées et vomissements postopératoires (NVPO), un traitement antiémétique combiné de dexaméthasone et d'ondansétron est recommandé. Il n'a pas été démontré que la métoclopramide procurait des avantages supplémentaires lorsqu'elle était combinée à d'autres antiémétiques. Le dropéridol est efficace, mais sa notice comprend toujours un encadré concernant le risque de dysrythmie. Parmi les analgésiques efficaces chez cette population de patients, citons l'acétaminophène, les médicaments anti-inflammatoires non stéroïliens (AINS), les blocs péribulbaires et les blocs sous-ténoniens. Les gouttes de 
tétracaïne topique ont donné des résultats mitigés, et il a été démontré que les gouttes d'anti-inflammatoire non stéroüdien topiques sont efficaces. L'utilisation d'opioïdes devrait être minimisée en raison de l'incidence accrue de NVPO.

Conclusion Si l'on veut offrir des soins optimaux aux enfants subissant une chirurgie pour strabisme, il est important de comprendre les considérations anesthésiques particulières d'une telle chirurgie et de réaliser à quel point chaque décision concernant la technique anesthésique peut avoir un impact sur ces considérations.

\section{Objectifs de ce module de développement professionnel continu (DPC)}

\section{À la fin de ce module de DPC, le lecteur sera capable de :}

1. Réaliser une évaluation préopératoire exhaustive en portant attention aux maladies et syndromes existant conjointement aux manifestations oculaires;

2. Évaluer la possibilité d'une incidence accrue de spasme du masséter ou d'hyperthermie maligne chez cette population de patients;

3. Décrire en détail un plan anesthésique pour une chirurgie du strabisme, notamment la prise en charge des voies aériennes et le choix d'agents anesthésiques;

4. Comprendre le mécanisme sous-tendant les réflexes oculocardiaque et oculorespiratoire et reconnaître les facteurs de risque associés et leur traitement;

5. Définir les options d'analgésie pour une chirurgie du strabisme; et

6. Préparer une prophylaxie antiémétique basée sur des données probantes pour les chirurgies du strabisme.

\section{Synthèse}

La chirurgie du strabisme est l'intervention ophtalmique pédiatrique la plus fréquemment réalisée. ${ }^{1,2}$ L'objectif de ce module de développement professionnel continu est de passer en revue les problèmes anesthésiques particuliers auxquels un patient devant subir une chirurgie du strabisme est exposé. Il est essentiel d'être conscient des questions et problèmes spécifiques à cette intervention, comme par exemple de l'association entre le strabisme et certains syndromes et maladies spécifiques, la survenue du réflexe oculocardiaque, et le risque accru de nausées et vomissements postopératoires. Les effets des diverses techniques d'anesthésie sur le réflexe oculocardiaque (ROC) et la prise en charge des nausées et vomissements postopératoires (NVPO) seront également abordés dans ce module.

\section{Le strabisme et la chirurgie du strabisme}

Le strabisme est un mauvais alignement oculaire qui provoque la perte de la vision binoculaire et l'amblyopie (perte de vision dans un ail normal d'un point de vue structurel). ${ }^{3}$ Le strabisme est prévalent chez 2-7\% des enfants $^{2-5}$ et se manifeste en général entre un et quatre ans. ${ }^{6}$ Le mauvais alignement présent chez les nouveau-nés se résout la plupart du temps avant l'âge de trois mois; après cela, il est considéré comme anormal. ${ }^{6}$ La plupart des cas se manifestant à la fin de l'enfance ou chez l'adulte sont en général la récurrence d'un strabisme qui n'avait été que partiellement traité; toutefois, dans le cas d'une nouvelle manifestation de strabisme, il est important de réaliser un examen neurologique. ${ }^{6}$ Les objectifs de la chirurgie sont de restaurer l'alignement des yeux afin de conserver une acuité visuelle (c.-à-d. pas d'amblyopie), de procurer une bonne correction cosmétique (orthotropie), d'améliorer la perception de profondeur (vision stéréoscopique) et d'éliminer la double vision. ${ }^{4-6}$ La maturité visuelle survient vers cinq ans, c'est pourquoi il est important de réparer le strabisme pendant la petite enfance. ${ }^{6}$

\section{L'intervention}

L'intervention chirurgicale comprend une incision à travers la conjonctive et la capsule du globe oculaire puis la localisation des muscles et l'exposition de leurs points d'insertion. Ensuite, le chirurgien repositionne les muscles extra-oculaires, en général en posant l'un des trois gestes suivants : 1) la récession, soit l'affaiblissement d'un muscle par la relocalisation plus postérieure de son point d'insertion; 2) la résection, soit le renforcement d'un muscle par l'élimination d'une partie du muscle; ou 3) la transposition, soit la modification de l'action du muscle par la connexion du muscle à un nouveau site. ${ }^{2,4}$ Il est difficile d'évaluer l'étendue de la correction nécessaire; pour cette raison, la chirurgie a parfois pour résultat une sur-correction ou, au contraire, une sous-correction, et une autre chirurgie est alors nécessaire. ${ }^{6}$ Bien que rares, les complications liées à ce type de chirurgie comprennent l'infection, le glissement du muscle opéré, une légère sensibilité, une vision floue causée par les médicaments ou le larmoiement, et une importante perte de la vision provoquée par une infection intra-oculaire ou un détachement rétinien lié à la perforation du globe..$^{2,4,6}$

Le test de duction forcée

Les ophtalmologistes peuvent tester l'amplitude du mouvement des muscles extra-oculaires de façon à établir 
la distinction entre une restriction paralytique et une restriction mécanique. Les résultats de ce test peuvent avoir des répercussions sur la technique chirurgicale. Plusieurs manuels d'anesthésie affirment que le chirurgien pourrait exiger l'administration de curares non dépolarisants afin de ne pas fausser le test; toutefois, une telle situation est rare dans la pratique clinique. Il faut éviter d'administrer de la succinylcholine parce que cet agent provoque une dépolarisation et une contraction musculaire prolongées (environ $20 \mathrm{~min}$ ) des muscles extra-oculaires, ce qui pourrait mener à des conclusions erronées du test de duction forcée. ${ }^{2,5}$

\section{Pathologies associées}

La plupart des enfants se présentant pour une chirurgie du strabisme sont en bonne santé, et près de la moitié des patients présentant un strabisme auront des antécédents familiaux positifs de strabisme. ${ }^{2}$ Lorsque le strabisme survient sans anomalie neurologique, sa cause précise est inconnue. Les anomalies neurologiques associées sont la paralysie cérébrale, la myéloméningocèle, l'hydrocéphalie, les syndromes crâniofaciaux, la maladie de von Recklinghausen, les troubles convulsifs ou les anomalies structurelles de l'œil. ${ }^{2,5,6}$ Il existe des facteurs de risque de strabisme non spécifiques, comme par exemple le trouble d'hyperactivité avec déficit de l'attention, le tabagisme maternel et une naissance prématurée. ${ }^{2}$ Pendant l'évaluation avant l'anesthésie, il est important d'envisager les pathologies et syndromes (voir tableau 1) associés au strabisme tels que les cardiopathies congénitales, étant donné que chacun de ces syndromes implique des considérations anesthésiques particulières qu'il importe de passer en revue.

Hyperthermie maligne / spasme du masséter

La suggestion selon laquelle il existe une incidence accrue d'hyperthermie maligne (HM) et de spasme du masséter (SM) chez les patients souffrant de strabisme est sujette à controverse. Par le passé, une association entre la HM et les patients subissant une chirurgie du strabisme a été rapportée, étant donné qu'il a été noté que les patients avec une HM présentaient une incidence plus élevée d'anomalies musculosquelettiques, strabisme et ptose compris. ${ }^{9}$ Par la suite, une revue de plus de 2500 patients chez qui la susceptibilité à la HM avait été testée n'a pas démontré d'association entre la HM et les patients devant subir une chirurgie du strabisme. ${ }^{9}$ Comme Girard et Litman l'écrivent dans un éditorial, « les anesthésiologistes se souviendront peut-être d'un temps où le strabisme était considéré comme un facteur de risque prédisposant à une susceptibilité à la HM. Bien entendu, ce n'est plus le cas; l'anesthésie des enfants souffrant de strabisme est désormais une intervention de routine réalisée à l'aide d'agents anesthésiques par inhalation et ce, sans augmentation apparente de l'incidence de HM. ${ }^{10}$ En outre, des études plus anciennes décrivaient une incidence quadruplée de SM chez les enfants devant subir une chirurgie du strabisme, comparativement à leurs pendants sans strabisme, après une induction de l'anesthésie à l'halothane suivie d'une dose unique de succinylcholine. ${ }^{5}$

Tableau 1 Syndromes congénitaux et anomalies chromosomiques associés au strabisme

\begin{tabular}{ll}
\hline Syndrome & Considérations anesthésiques \\
\hline Syndrome d'Apert & Possibilité d'intubation difficile, possibilité de sténose choanale, fusion cervicale, coronaropathie (10 \%) \\
Syndrome du cri du chat & Micrognathie, possibilité d'intubation difficile, hypotonie, tendance à l'hypothermie, coronaropathie (33 \%) \\
Syndrome de Crouzon & Possibilité d'intubation difficile, possibilité de pression intracrânienne élevée \\
Syndrome de Down & Trisomie 21, obstruction des voies aériennes, instabilité atlanto-axiale, coronaropathie (50\%) \\
Syndrome de Goldenhar & $\begin{array}{c}\text { Microsomie hémifaciale, possibilité d'anomalies de la colonne cervicale, possibilité d'intubation } \\
\text { et de ventilation au masque difficiles, coronaropathies rares, et hydrocéphalie }\end{array}$ \\
Homocystinurie & $\begin{array}{c}\text { Habitus marfanoïde accompagné de cyphoscoliose et de déformation sternale, tendance aux complications } \\
\text { thromboemboliques et à l'hypoglycémie }\end{array}$ \\
Syndrome de Marfan & $\begin{array}{c}\text { Dilatation de l'artère aortique ou pulmonaire, maladie de la valve aortique ou mitrale, pectus excavatum, } \\
\text { risque de pneumothorax }\end{array}$ \\
Syndrome de Moebius & $\begin{array}{c}\text { Possibilité d'intubation difficile, micrognathie, sécrétions copieuses, possibilité d'anomalies de la colonne } \\
\text { cervicale }\end{array}$ \\
Dystrophie myotonique & $\begin{array}{c}\text { Tendance aux contractions myotoniques, aux contractions associées à la succinylcholine et à l'hyperkaliémie, } \\
\text { anomalies fréquentes de conduction cardiaque, sensibilité aux dépresseurs du système nerveux central }\end{array}$ \\
Syndrome de Stickler & $\begin{array}{c}\text { Possibilité d'intubation difficile, micrognathie, prolapsus de la valve mitrale, habitus marfanoïde, scoliose, } \\
\text { cyphose }\end{array}$ \\
Syndrome de Turner & Possibilité d'intubation et d'accès intraveineux difficiles, coronaropathie
\end{tabular}

Extraits d'un tableau réimprimé de Smith's Anesthesia for Infants and Children, $7^{\text {th }}$ ed. Motoyamo EK, Davis PJ (Eds). Chapter 22: Anesthesia for pediatric ophthalmic surgery, page 774, Table 22-1. Droits d'auteur (2006), avec la permission d'Elsevier 
Dans une autre étude, des résultats contradictoires ont été obtenus chez des patients sains strabiques et non strabiques. Cette étude a démontré que la succinylcholine administrée à la suite d'une anesthésie à l'halothane provoquait une augmentation semblable de la tension de la mâchoire et de l'intensité du bloc neuromusculaire; toutefois, l'étude ne comptait que huit participants dans chaque groupe. ${ }^{11} \mathrm{Il}$ n'existe malheureusement pas de mesure objective du SM et il peut être difficile à dépister. Les «mâchoires d'acier » sont un état clinique pendant lequel la mandibule ne peut être décollée du maxillaire pour faciliter l'insertion d'un appareil de ventilation. Plusieurs pensent que certains cas de SM pourraient être une réaction normale à la succinylcholine. ${ }^{9,10}$ En résumé, il semble que l'association entre strabisme et HM ne soit plus d'actualité; toutefois, si un SM est suspecté chez un patient, il est important d'être conscient que ce patient pourrait manifester une HM. ${ }^{9,12}$ Nous répétons qu'il est important d'obtenir des antécédents familiaux détaillés en matière d'anesthésie.

\section{Le réflexe oculocardiaque}

\section{Définition}

En règle générale, le réflexe oculocardiaque (ROC) se définit par une réduction de $20 \%$ de la fréquence cardiaque (FC) par rapport aux valeurs de base, des dysrythmies, ou une pause sinusale associée à une traction du muscle oculaire. ${ }^{13-17}$ Dans d'autres études, la définition de ce réflexe comprend une réduction de 10-30\% de la FC par rapport aux valeurs de base. ${ }^{18-20} \mathrm{Il}$ s'agit d'un réflexe des nerfs trijumeau et vague qui peut provoquer toutes sortes d'arythmies, notamment la bradycardie sinusale, un rythme nodal, un foyer auriculaire ectopique, un bloc auriculo-ventriculaire, un bigéminisme ventriculaire, un rythme multifocal, des contractions ventriculaires multifocales prématurées, un rythme idioventriculaire, une tachycardie ventriculaire ou encore une asystole., ${ }^{2,5}$ L'incidence de ROC pendant les chirurgies du strabisme varie de 14-90\% selon l'administration d'un agent anticholinergique, le choix des agents anesthésiques et la définition de ROC retenue., $5,14,15,18,19,21,22$

\section{Éléments déclencheurs}

Outre la traction exercée sur les muscles extra-oculaires, la pression sur les structures orbitales ou sur le tissu restant dans la fente sphénoïdale après l'énucléation est un autre élément déclencheur de ROC, tout comme un traumatisme oculaire ou l'augmentation de la pression intra-orbitale due à une injection ou un hématome. ${ }^{5,7,18}$ On pense que le ROC est plus fréquent lors de la traction du muscle droit médial $;{ }^{14,23}$ Blanc et coll. ${ }^{24}$ n'ont cependant pas pu démontrer que ce muscle déclenche un ROC plus souvent que les autres muscles extra-oculaires avec le même type de stimulus. Le ROC est un phénomène gradué par lequel la bradycardie s'aggrave et survient plus rapidement si la tension est abrupte et soutenue. ${ }^{23}$ Cette réaction disparaît généralement lorsque la stimulation est interrompue. On appelle ce phénomène échappement vagal, ou épuisement du ROC. Il s'agit d'un mécanisme de défense physiologique par lequel le changement de FC est attenué après une manipulation musculaire extra-oculaire soutenue ou répétée.

\section{Réflexe oculorespiratoire}

Le réflexe oculorespiratoire a les mêmes déclencheurs que le ROC, mais il a pour résultat une réduction du volume courant et de la fréquence respiratoire. ${ }^{13}$ Les voies afférentes sont les mêmes que dans les cas de ROC mais elles sont dirigées vers la zone du contrôle respiratoire du tronc cérébral, et les fibres efférentes se retrouvent dans le nerf phrénique et les autres nerfs impliqués dans la respiration. Le réflexe oculorespiratoire peut provoquer de l'hypercapnie et de l'hypoxémie, lesquelles peuvent augmenter l'incidence de ROC.

\section{Prévention du ROC}

Voici les principes de base de la prévention d'un ROC : le chirurgien doit prévenir son équipe avant de manipuler les muscles extra-oculaires, la manipulation chirurgicale doit être douce, la profondeur de l'anesthésie doit être suffisante, et l'hypoxie et l'hypercarbie doivent être évitées. ${ }^{2}$ L'administration d'atropine ou de glycopyrrolate réduit l'incidence de ROC; ;,5,23,25 toutefois, l'administration systématique d'agents anticholinergiques en prophylaxie était controversée par le passé en raison d'une association avec des arythmies ventriculaires. De plus, dans la plupart de ces comptes-rendus, les patients ont reçu une anesthésie à l'halothane, ce qui a également augmenté l'incidence d'arythmies. Afin d'éviter d'interférer avec les résultats des études, les médicaments anticholinergiques n'ont pas été utilisés dans la majorité des études récentes évaluant les effets de divers médicaments anesthésiques sur l'incidence de ROC. Malgré cela, la FC est revenue à sa valeur de base lors du relâchement du muscle extra-oculaire dans la majorité des cas et ce, avec une intervention minimale. Ces études ont démontré que l'incidence de ROC est significativement affectée par le type d'agent anesthésique administré. Il a également été suggéré d'utiliser les traitements anticholinergiques en prophylaxie pour réduire les taux de NVPO en réduisant l'incidence de ROC; 
toutefois, cette alternative n'a pas été testée chez une cohorte d'enfants atteints de strabisme. ${ }^{25}$

\section{Traitement}

La réaction initiale au $\mathrm{ROC}$ est de demander au chirurgien de cesser immédiatement la manipulation chirurgicale, d'évaluer l'état ventilatoire du patient pour écarter l'hypercarbie et l'hypoxie, puis d'évaluer la profondeur de l'anesthésie. ${ }^{5,7}$ En règle générale, la $\mathrm{FC}$ revient à sa valeur de base assez rapidement lorsque la stimulation est interrompue. ${ }^{2}$ Il faut administrer de l'atropine si de l'instabilité hémodynamique ou des arythmies surviennent en raison d'une bradycardie.

\section{Nausées et vomissements postopératoires}

La survenue de NVPO après une chirurgie du strabisme demeure un problème important. L'incidence des NVPO sans prophylaxie varie de $37-90 \%,{ }^{2,26,27}$ et des NVPO non traités peuvent créer des complications, notamment la déshydratation, le déséquilibre électrolytique, ${ }^{7} 1$ 'hémorragie sous-conjonctivale, le desserrement des attaches chirurgicales, un congé retardé et des admissions imprévues. ${ }^{2}$ De plus, les NVPO pourraient diminuer la satisfaction et augmenter l'utilisation des ressources. ${ }^{26,28}$

Parmi les principaux facteurs de risque de vomissements postopératoires (VPO) en chirurgie pédiatrique, on compte le type de chirurgie (par ex., chirurgie du strabisme, amygdalectomie), un âge $>$ trois ans, une durée de l'anesthésie $>30 \mathrm{~min}$, ainsi que des antécédents personnels ou familiaux de VPO, de NVPO, ou de mal des transports. $^{7,26}$ En outre, certains facteurs de risque spécifiques aux chirurgies du strabisme augmentent l'incidence de VPO. Parmi ces facteurs, citons le réflexe oculo-émétique (un réflexe central lié à la manipulation des muscles oculaires), ${ }^{7,27}$ un changement postopératoire de la perception visuelle, ${ }^{7}$ un ROC positif, $^{7}$ la technique chirurgicale $^{29}$ et le nombre de muscles oculaires réparés. $^{26,30}$ La myopexie, ${ }^{29}$ une technique chirurgicale grâce à laquelle la fixation postérieure du muscle par une suture résulte en une stimulation plus soutenue, est associée à une incidence accrue de VPO.

\section{Antiémétiques}

La plupart des données probantes portant sur les prophylaxies antiémétiques chez l'enfant se limitent aux VPO comme critère d'évaluation, étant donné qu'il est difficile de dépister la nausée chez les enfants. ${ }^{26}$ De plus, il est difficile de comparer les différentes études étant donné la diversité des techniques anesthésiques, des médicaments et des critères d'évaluation choisis. La littérature se concentre principalement sur les antiémétiques en prophylaxie plutôt qu'en traitement chez les patients pédiatriques strabiques. La plupart des médicaments antiémétiques étudiés dans cette section sont administrés par voie intraveineuse. Il a été démontré que le dimenhydrinate $0,5 \mathrm{mg} \cdot \mathrm{kg}^{-1}$ était plus efficace qu' un placebo (incidence des VPO $10 \%$ vs $38 \%$, respectivement); toutefois, les courbes de dose-réponse, le moment d'administration optimal et les avantages de doses répétées sont inconnus, et nous ne savons pas si le dimenhydrinate provoque une sédation ou un congé retardé. ${ }^{26}$ En 1995, une revue méthodique avec des nombres de sujets à traiter (NST) de quatre et 2,5 a démontré que des doses de métoclopramide de 0,15 et $0,25 \mathrm{mg} \cdot \mathrm{kg}^{-1}$, respectivement, étaient plus efficaces seules que le placebo seulement pour prévenir les vomissements précoces jusqu'à six heures. ${ }^{31}$ La même revue avec un NST de quatre patients a conclu que le dropéridol $75 \mu \mathrm{g} \cdot \mathrm{kg}^{-1}$ est la dose la plus efficace pour éviter un épisode de vomissement. ${ }^{31}$ Lorsque la sédation postopératoire des patients chirurgicaux en ambulatoire est devenue un problème, l'utilisation de dropéridol a tout d'abord baissé, puis son utilisation a encore chuté en 2001 lorsqu'un encadré controversé a été publié par la Food and Drug Administration selon lequel le dropéridol à forte dose provoquait la prolongation du QT. ${ }^{26}$ Lors d'une comparaison des antiémétiques, il a été observé que l'ondansétron et le dropéridol étaient plus efficaces que le métoclopramide et le placebo pour réduire les NVPO avant le congé (incidence de $5 \%, 5 \%, 32 \%$, et $25 \%$, respectivement); toutefois, il n'y a pas eu de différence entre les groupes lors de l'évaluation des NVPO après le congé (incidence de $25 \%, 25 \%, 20 \%$, et $25 \%$, respectivement). ${ }^{26} \mathrm{La}$ dexaméthasone et l'ondansétron sont des antiémétiques fréquemment utilisés dans la chirurgie du strabisme chez l'enfant. Dans des études de détermination de dose, il a été observé qu'une dose de $50 \mu \mathrm{g} \cdot \mathrm{kg}^{-1}$ de dexaméthasone était tout aussi efficace que des doses plus élevées, comme par exemple $250 \mu \mathrm{g} \cdot \mathrm{kg}^{-1}$ (incidence de NVPO $42,9 \%$ et $40,9 \%$, respectivement; placebo $92,9 \%)^{32}$ et qu'une dose de $250 \mu \mathrm{g} \cdot \mathrm{kg}^{-1}$ de dexaméthasone était tout aussi efficace qu' une dose de $1 \mathrm{mg} \cdot \mathrm{kg}^{-1}$ (incidence de VPO $26 \%$ et $21 \%$, respectivement; placebo $66 \%){ }^{33}$ L'ondansétron était efficace à des doses allant de $0,05-0,2 \mathrm{mg} \cdot \mathrm{kg}^{-1}$ et ne provoquait que très peu d'effets secondaires. $^{2,26,27,31,34}$ Lors de l'évaluation du bon moment pour administrer l'ondansétron, il a été observé que $100 \mu \mathrm{g} \cdot \mathrm{kg}^{-1}$ étaient tout aussi efficaces, que la dose soit administrée avant ou après la manipulation du muscle oculaire (incidence de VPO $35 \%$ vs $33 \%$, respectivement) ${ }^{26}$ toutefois, l'administration d'une dose en prophylaxie plutôt qu'en traitement des symptômes a permis de réduire le temps jusqu'au congé et a amélioré la satisfaction globale à un moindre coût. ${ }^{26}$ Comparativement à 
l'utilisation de propofol pour l'induction et le maintien de l'anesthésie, il a été observé qu'une dose de $150 \mu \mathrm{g} \cdot \mathrm{kg}^{-1}$ d'ondansétron (avec halothane, protoxyde d'azote et oxygène) était tout aussi efficace pour réduire les VPO pour une chirurgie du strabisme chez l'enfant (incidence des VPO $26 \%$ vs $27 \%$, respectivement). ${ }^{26}$ D'autres antagonistes de la sérotonine (granisétron, ramosétron) ont été étudiés et ont donné des résultats positifs, mais ces agents n'offraient pas d'avantages significatifs par rapport à l'ondansétron. ${ }^{26}$ Enfin, il a été observé que l'acupressure au point d'acupuncture P6, une forme moins courante de traitement antiémétique, était efficace. ${ }^{7,26,35}$

Thérapie antiémétique combinée

Il est recommandé d'administrer une thérapie antiémétique combinée composée de différentes classes de médicaments aux patients présentant un risque élevé de manifester des nausées et vomissements. ${ }^{7,26}$ De nombreuses études ont démontré que la combinaison d'ondansétron et de dexaméthasone est plus efficace que l'un ou l'autre de ces agents seuls (voir tableau 2). ${ }^{26,36-38}$ En outre, la combinaison de dropéridol et d'ondansétron ou de granisétron est plus efficace pour réduire les VPO que l'administration seule de l'un de ces médicaments. ${ }^{26}$ En revanche, lorsque le métoclopramide est ajouté au dropéridol ou à l'ondansétron, il n'est pas plus efficace que ces agents administrés seuls pour réduire les symptômes antiémétiques. $^{26}$

\section{Technique d'anesthésie}

Les incidences de NVPO et de ROC lors de chirurgies du strabisme sont influencées par de nombreux facteurs, notamment la technique d'anesthésie (voir tableau 3).

\section{Prémédication}

Si le midazolam est utilisé comme prémédication, il pourrait avoir un effet antiémétique bénéfique. ${ }^{39}$ Il a été démontré que les autres benzodiazépines, comme le lorazépam et le diazépam, réduisaient les VPO chez les patients de chirurgie du strabisme, ${ }^{2,26}$ alors que l'utilisation de clonidine orale en dose de $2-4 \mu \mathrm{g} \cdot \mathrm{kg}^{-1}$ en prémédication a donné des résultats mitigés. ${ }^{7,26}$

\section{Voies aériennes}

La chirurgie du strabisme chez l'enfant est réalisée sous anesthésie générale en décubitus dorsal. Par le passé, une sonde endotrachéale était en général utilisée pour la prise en charge des voies aériennes. Depuis, le masque laryngé $\left(\mathrm{LMA}^{\mathrm{TM}}\right)$ a gagné en popularité. Un sondage réalisé au Royaume-Uni en 1999 a démontré que $60 \%$ des anesthésiologistes utilisaient un $\mathrm{LMA}^{\mathrm{TM}}$ chez les enfants subissant une chirurgie du strabisme. ${ }^{1}$ Un contrôle prospectif portant sur 94 patients subissant une chirurgie ophtalmique (principalement des chirurgies du strabisme) avec un $\mathrm{LMA}^{\mathrm{TM}}$ a rapporté une faible incidence de complications. ${ }^{40}$
Tableau 2 Thérapie antiémétique combinée : ondansétron et dexaméthasone

$\mathrm{VPO}=$ vomissements postopératoires

Tableau 3 Facteurs ayant une influence sur l'incidence du réflexe oculocardiaque

\begin{tabular}{lll}
\hline Auteur & Médicaments & $\begin{array}{l}\text { Incidence de } \\
\text { VPO (24 h) }\end{array}$ \\
\hline Splinter et coll. $^{36}$ & $\circ$ Ondansétron $150 \mu \mathrm{g} \cdot \mathrm{kg}^{-1}$ & $28 \%$ \\
& $\circ$ Ondansétron $50 \mu \mathrm{g} \cdot \mathrm{kg}^{-1}+$ Dexaméthasone $150 \mu \mathrm{g} \cdot \mathrm{kg}^{-1}$ & $9 \%$ \\
Splinter $^{37}$ & $\circ$ Dexaméthasone $150 \mu \mathrm{g} \cdot \mathrm{kg}^{-1}$ & $23 \%$ \\
& $\circ$ Dexaméthasone $150 \mu \mathrm{g} \cdot \mathrm{kg}^{-1}+$ Ondansétron $50 \mu \mathrm{g} \cdot \mathrm{kg}^{-1}$ & $5 \%$ \\
Bhardwaj et coll. $^{38}$ & $\circ$ Placebo & $64,5 \%$ \\
& $\circ$ Ondansétron $150 \mu \mathrm{g} \cdot \mathrm{kg}^{-1}$ & $33,3 \%$ \\
& $\circ$ Ondansétron $150 \mu \mathrm{g} \cdot \mathrm{kg}^{-1}+$ Dexaméthasone $200 \mu \mathrm{g} \cdot \mathrm{kg}^{-1}$ & $10 \%$ \\
\hline
\end{tabular}

\begin{tabular}{|c|c|c|}
\hline Augmentation & Réduction & Pas d'effet \\
\hline Propofol $^{2,15,18,22,26,31}$ & Anticholinergiques ${ }^{2,5,23,25}$ & Sévoflurane $=$ desflurane ${ }^{17}$ \\
\hline Anesthésie légère ${ }^{20}$ & Kétamine $^{14,18}$ & Ventilation spontanée \\
\hline Hypercarbie $^{24}$ & Midazolam $^{14}$ & Ventilation contrôlée \\
\hline Hypoxie $^{24}$ & Rocuronium $^{19}$ & \\
\hline Traction sur les muscles extra-oculaires ${ }^{23,24}$ & & \\
\hline Stimulation des structures orbitales ${ }^{5,17,18}$ & & \\
\hline Halothane $>$ sévoflurane $e^{13}$ & & \\
\hline Rémifentanil > sévoflurane, desflurane ${ }^{15,16}$ & & \\
\hline
\end{tabular}




\section{Ventilation}

La ventilation spontanée ou contrôlée peut être utilisée, mais il faut garder à l'esprit que l'hypercarbie peut augmenter l'incidence de ROC. ${ }^{24}$ Une étude a examiné l'effet de la concentration d'oxygène inspiré sur l'incidence des NVPO. Treshan et coll. ont évalué la différence entre l'utilisation d'une fraction d'oxygène inspiré de 0,3 avec de l'air, d'une fraction d'oxygène inspiré de 0,8 avec de l'air, ou d'une fraction d'oxygène inspiré de 0,3 avec de l'air et une dose d'ondansétron de $75 \mu \mathrm{g} \cdot \mathrm{kg}^{-1}$. Ils n'ont trouvé aucune différence significative du point de vue statistique entre les groupes, malgré l'hypothèse qu'une fraction d'oxygène accrue pendant l'opération réduisait les NVPO. ${ }^{41}$ L'effet du protoxyde d'azote sur les NVPO est sujet à controverse. Des études chez l'adulte ont montré que l'élimination de protoxyde d'azote réduisait les vomissements postopératoires; toutefois, les études chez l'enfant n'ont pas démontré le même effet, y compris une étude réalisée spécifiquement chez des patients subissant une chirurgie du strabisme. ${ }^{26,30}$

\section{Agents volatils}

La profondeur de l'anesthésie est importante, quelle que soit la technique d'anesthésie. Il a été démontré que, pendant une anesthésie au sévoflurane, des valeurs d'index bispectral $(\mathrm{BIS})>60$ étaient associées à une incidence accrue de ROC par rapport à des valeurs de BIS de $40 .^{20}$ L'halothane est plus susceptible de provoquer de la bradycardie, des dysrythmies, et des troubles de ventilation que le sévoflurane, ${ }^{13}$ alors qu'il n'y a pas de différence entre le sévoflurane et le desflurane et leurs effets sur le ROC. ${ }^{17}$

\section{Propofol}

Dans une étude, une perfusion de propofol pour maintenir l'anesthésie a réduit les VPO. ${ }^{2,26,31}$ Cependant, le propofol n'a pas réduit les VPO lorqu'il était utilisé à la place $\mathrm{du}$ thiopental pour l'induction seulement ou avec de l'isoflurane pour le maintien dans les deux groupes. ${ }^{42}$ Malgré l'avantage que présente le propofol-soit de réduire les VPO chez les enfants devant subir une chirurgie du strabisme, il provoque malheureusement une incidence accrue de ROC par rapport aux autres anesthésiques. ${ }^{2,15,18,22,26,31}$

\section{Kétamine}

Hahnenkamp et coll. ${ }^{18}$ ont comparé quatre techniques d'anesthésie et leurs effets sur le ROC. Les groupes étaient les suivants : perfusions de propofol et d'alfentantil, perfusions de kétamine et de midazolam, sévoflurane ou halothane. Le groupe kétamine et midazolam a subi le moins de changements hémodynamiques causés par un ROC. De plus, une autre étude évaluant la kétamine a démontré qu'un bolus unique de kétamine à $1 \mathrm{ou} 2 \mathrm{mg} \cdot \mathrm{kg}^{-1}$ pour l'induction réduisait l'incidence de ROC comparativement à une combinaison propofol-sévoflurane. ${ }^{14}$ Un des mécanismes avancés qui explique ce phénomène est l'augmentation du tonus sympathique associée à la kétamine qui contrecarre la stimulation parasympathique du ROC.

\section{Curares}

Les curares étaient plus fréquemment utilisés chez les patients atteints de strabisme lorsque l'intubation trachéale était la méthode principale utilisée pour la prise en charge des voies aériennes. Une étude comparant des curares plus anciens suggère que le pancuronium réduit l'incidence de bradycardie ou les arythmies comparativement à l'atracurium, au vécuronium ou à la tubocurarine. Des études plus récentes évaluant le rocuronium ont montré qu'il réduisait la fréquence de ROC mais pas des VPO; toutefois, l'étude ne mentionne pas si des agents décurarisants ont été utilisés. $^{19}$

Liquides

Afin de maintenir une hydratation préopératoire, il est recommandé de permettre l'ingestion de liquides clairs jusqu'à deux ou trois heures avant l'opération, puis d'hydrater généreusement le patient pendant l'opération à l'aide de cristalloïdes intraveineux, ce qui permettra de réduire les NVPO. ${ }^{5,27}$ De plus, une étude récente a conclu qu'une solution lactate Ringer intraveineuse à $30 \mathrm{~mL} \cdot \mathrm{kg}^{-1} \cdot \mathrm{h}^{-1}$ pendant l'opération réduisait les NVPO chez les patients de chirurgie du strabisme de façon plus efficace qu'une solution à $10 \mathrm{~mL} \cdot \mathrm{kg}^{-1} \cdot \mathrm{h}^{-1}$. 43

\section{Analgésie}

Une analgésie postopératoire optimale est essentielle étant donné que son absence pourrait contribuer aux NVPO, à la détresse émotionnelle ou à un congé retardé en cas de non-traitement. $^{27}$ En 2008, l'Association of Paediatric Anaesthetists of Great Britain and Ireland a publié des directives d'analgésie pour certaines interventions, notamment des recommandations pour les chirurgies du strabisme. ${ }^{44} \mathrm{Il}$ y avait trois recommandations de grade B :

1. Les blocs peropératoires d'anesthésiques locaux (sous-ténoniens ou péribulbaires) réduisent les NVPO 
et pourraient améliorer l'analgésie périopératoire par rapport aux opioïdes intraveineux.

2. Les médicaments anti-inflammatoires non stéroïdiens (AINS) topiques n'améliorent pas les scores de douleur ou les besoins analgésiques postopératoires comparativement aux anesthésiques locaux topiques ou à un placebo.

3. Les opioïdes et AINS peropératoires procurent une analgésie postopératoire similaire, mais l'utilisation d'opioïdes est associée à une augmentation des NVPO.

\section{Opioïdes}

Idéalement, l'utilisation d'opioïdes devrait être minimisée en administrant de l'acétaminophène et des AINS. ${ }^{2}$ Une étude comparant l'effet du fentanyl, de la mépéridine et du bloc péribulbaire combinés à une perfusion de propofol sur les VPO a conclu que le groupe mépéridine présentait l'incidence de VPO la plus élevée; le bloc péribulbaire affichait l'incidence la plus basse, et le fentanyl était entre deux. ${ }^{45}$ D'autres études ont démontré que le fentanyl augmentait les NVPO après une chirurgie du strabisme; ${ }^{2}$ toutefois, une technique combinée de propofol et de sufentanil a provoqué moins de NVPO par rapport à une technique combinée de propofol et isoflurane. ${ }^{26} \mathrm{Il}$ a été démontré que le rémifentanil augmentait le degré de bradycardie induite par le ROC comparativement au sévoflurane et au desflurane. ${ }^{15,16}$ Lors d'une comparaison des effets du rémifentanil et du fentanyl, aucune différence n'a été observée quant à l'incidence de VPO et, sans surprise, les patients recevant du rémifentanil avaient des scores de douleur plus élevés. ${ }^{7,26}$

\section{Analgésiques topiques}

L'efficacité de la tétracaïne topique a été démontrée dans deux études séparées; ${ }^{46,47}$ toutefois, deux autres études n'ont pas montré d'avantage. ${ }^{48,49}$ Certaines données soutiennent une association entre le diclofénac topique ${ }^{50}$ et une excellente analgésie accompagnée d'une faible incidence de NVPO, mais cet avantage n'a pas été démontré avec le kétorolac. ${ }^{49}$

\section{Blocs}

Les blocs régionaux sont plus souvent réalisés chez des patients adultes, étant donné que l'intervention est souvent terminée sous sédation intraveineuse. Tous les blocs peuvent avoir leur lot de complications, c'est pourquoi on a tendance à les éviter chez les enfants qui sont souvent sous anesthésie générale.

\section{Conclusion}

La chirurgie du strabisme est l'intervention ophtalmique pédiatrique la plus courante. Bien que l'hyperthermie maligne ne constitue plus une préoccupation dans les soins prodigués à ces patients, le ROC et les NVPO sont encore des facteurs importants à prendre en considération lors de toute décision concernant la technique d'anesthésie. Une bonne compréhension des considérations anesthésiques particulières pour une telle chirurgie est essentielle si l'on souhaite offrir des soins optimaux.

\section{Cas clinique}

Un garçon de deux ans se présente à la salle d'opération de l'hôpital pédiatrique pour une correction du strabisme de son œil gauche. Il ne prend pas de médicaments et n'a pas d'allergies. Il s'agit de sa première anesthésie et il n'y a pas d'antécédents familiaux de réactions à l'anesthésie. Vous êtes l'anesthésiologiste consultant responsable du cas.

\section{Directives pour compléter le module de développement professionnel continu (DPC)}

1. Lisez les références en gras.

2. Rendez-vous à : https://www.cpass2.umontreal.ca/self assessmentprogram/ ; et choisissez le module actuel (Prise en charge de l'anesthésie pour une chirurgie du strabisme chez l'enfant).

3. Répondez aux questions à choix de réponses concernant le cas clinique.

4. Une fois que vous avez saisi toutes vos réponses, vous aurez accès aux explications d'experts pour tous les choix possibles.

5. Les participants peuvent réclamer un maximum de quatre heures de DPC pour un total de huit crédits sous la Section 3 du programme de DPC du Collège royal des médecins et chirurgiens du Canada.

Acknowledgements The assistance provided by Dr. Kenneth Romanchuk and the Department of Anesthesia at the Alberta Children's Hospital is much appreciated.

Competing interests None declared.

\section{References}

1. Dell R, Williams $B$. Anesthesia for strabismus surgery: a regional review. Br J Anaesth 1999; 82: 761-3.

2. Mills $M D$. Perianesthesia care of adult and pediatric strabismus surgery patients. J Perianesth Nurs 1998; 13: 16-25. 
3. Engle EC. The genetic basis of complex strabismus. Pediatr Res 2006; 59: 343-8.

4. Huddleston KR. Strabismus repair in the pediatric patient. AORN J 1994; 60: 754-60.

5. McGoldrick KE. Principles of ophthalmic anesthesia. J Clin Anesth 1989; 1: 297-312.

6. Donahue SP. Clinical practice. Pediatric strabismus. N Engl J Med 2007; 356: 1040-7.

7. Gayer S, Tutiven J. Anesthesia for pediatric ocular surgery. Ophthalmol Clin North Am 2006; 19: 269-78.

8. Mansour AM, Bitar FF, Traboulsi EI, et al. Ocular pathology in congenital heart disease. Eye (Lond) 2005; 19: 29-34.

9. Hopkins PM. Malignant hyperthermia: advances in clinical management and diagnosis. Br J Anaesth 2000; 85: 118-28.

10. Girard T, Litman RS. Molecular genetic testing to diagnose malignant hyperthermia susceptibility. J Clin Anesth 2008; 20: 161-3.

11. Saddler JM, Bevan JC, Plumley MH, Polomeno RC, Donati F, Bevan DR. Jaw muscle tension after succinylcholine in children undergoin strabismus surgery. Can J Anaesth 1990; 37: 21-5.

12. O'Flynn RP, Shutack JG, Rosenberg H, Fletcher JE. Masseter muscle rigidity and malignant hyperthermia susceptibility in pediatric patients. An update on management and diagnosis. Anesthesiology 1994; 80: 1228-33.

13. Allison CE, De Lange JJ, Koole FD, Zuurmond WW, Ros HH, van Schagen NT. A comparison of the incidence of the oculocardiac and oculorespiratory reflexes during sevoflurane or halothane anesthesia for strabismus surgery in children. Anesth Analg 2000; 90: 306-10.

14. Choi SH, Lee SJ, Kim SH, et al. Single bolus of intravenous ketamine for anesthetic induction decreases oculocardiac reflex in children undergoing strabismus surgery. Acta Anaesthesiol Scand 2007; 51: 759-62.

15. Choi SR, Park SW, Lee JH, Lee SC, Chung CJ. Effect of different anesthetic agents on oculocardiac reflex in pediatric strabismus surgery. J Anesth 2009; 23: 489-93.

16. Chung CJ, Lee JM, Choi SR, Lee SC, Lee JH. Effect of remifentanil on oculocardiac reflex in paediatric strabismus surgery. Acta Anaesthesiol Scand 2008; 52: 1273-7.

17. Oh AY, Yun MJ, Kim HJ, Kim HS. Comparison of desflurane with sevoflurane for the incidence of oculocardiac reflex in children undergoing strabismus surgery. Br J Anaesth 2007; 99: 262-5.

18. Hahnenkamp K, Honemann $C W$, Fischer LG, Durieux ME, Muehlendyck $H$, Braun $U$. Effect of different anaesthetic regimes on the oculocardiac reflex during paediatric strabismus surgery. Paediatr Anaesth 2000; 10: 601-8.

19. Karanovic N, Carev M, Ujevic A, Kardum G, Dogas Z. Association of oculocardiac reflex and postoperative nausea and vomiting in strabismus surgery in children anesthetized with halothane and nitrous oxide. Paediatr Anaesth 2006; 16: 948-54.

20. $Y i C$, Jee D. Influence of the anaesthetic depth on the inhibition of the oculocardiac reflex during sevoflurane anaesthesia for paediatric strabismus surgery. Br J Anaesth 2008; 101: 234-8.

21. Goerlich TM, Foja C, Olthoff D. Effects of sevoflurane versus propofol on oculocardiac reflex-a comparative study in 180 children (German). Anaesthesiol Reanim 2000; 25: 17-21.

22. Tramer MR, Sansonetti A, Fuchs-Buder T, Rifat K. Oculocardiac reflex and postoperative vomiting in paediatric strabismus surgery. A randomised controlled trial comparing four anaesthetic techniques. Acta Anaesthiol Scand 1998; 42: 117-23.

23. Ohashi T, Kase M, Yokoi M. Quantitative analysis of the oculocardiac reflex by traction on human extraocular muscle. Invest Ophthalmol Vis Sci 1986; 27: 1160-4.

24. Blanc VF, Hardy JF, Milot J, Jacob JL. The oculocardiac reflex: a graphic and statistical analysis in infants and children. Can Anaesth Soc J 1983; 30: 360-9.
25. Chisakuta AM, Mirakhur RK. Anticholinergic prophylaxis does not prevent emesis following strabismus surgery in children. Paediatr Anaesth 1995; 5: 97-100.

26. Kovac $A L$. Management of postoperative nausea and vomiting in children. Paediatr Drugs 2007; 9: 47-69.

27. Williams AR, Conroy JM. The anesthetic management of the pediatric strabismus patient. J AAPOS 1998; 2: 113-5.

28. Watcha MF, Bras PJ, Cieslak GD, Pennant JH. The doseresponse relationship of ondansetron in preventing postoperative emesis in pediatric patients undergoing ambulatory surgery. Anesthesiology 1995; 82: 47-52.

29. Saiah M, Borgeat A, Ruetsch YA, Seifert B, Klainguti G. Myopexy (Faden) results in more postoperative vomiting after strabismus surgery in children. Acta Anaesthesiol Scand 2001; 45: 59-64.

30. Kuhn I, Scheifler G, Wissing $H$. Incidence of nausea and vomiting in children after strabismus surgery following desflurance anaesthesia. Paediatr Anaesth 1999; 9: 521-6.

31. Tramer M, Moore A, McQuay $H$. Prevention of vomiting after paediatric strabismus surgery: a systemic review using the numbers-needed-to-treat method. Br J Anaesth 1995; 75: 556-61.

32. Mathew PJ, Madan R, Subramaniam R, et al. Efficacy of lowdose dexamethasone for preventing postoperative nausea and vomiting following strabismus repair in children. Anaesth Intensive Care 2004; 32: 372-6.

33. Madan R, Bhatia A, Chakithandy $S$, et al. Prophylactic dexamethasone for postoperative nausea and vomiting in pediatric strabismus surgery: a dose ranging and safety evaluation study. Anesth Analg 2005; 100: 1622-6.

34. Davis A, Krige S, Moyes D. A double-blind randomized prospective study comparing ondansetron with droperidol in the prevention of emesis following strabismus surgery. Anaesth Intensive Care 1995; 23: 438-43.

35. Lee A, Fan LT. Stimulation of the wrist acupuncture point P6 for preventing postoperative nausea and vomiting. Cochrane Database Syst Rev 2009; (2): CDE003281.

36. Splinter WM, Rhine EJ. Low-dose ondansetron with dexamethasone more effectively decreases vomiting after strabismus surgery in children than does high-dose ondansetron. Anesthesiology 1998; 88: 72-5.

37. Splinter WM. Prevention of vomiting after strabismus surgery in children: dexamethasone alone versus dexamethasone plus lowdose ondansetron. Paediatr Anaesth 2001; 11: 591-5.

38. Bhardwaj N, Bala I, Kaur C, Chari P. Comparison of ondansetron with ondansetron plus dexamethasone for antiemetic prophylaxis in children undergoing strabismus surgery. J Pediatr Ophthalmol Strabismus 2004; 41: 100-4.

39. Riad W, Altaf $R$, Abdulla A, Oudan $H$. Effect of midazolam, dexamethasone and their combination on the prevention of nausea and vomiting following strabismus repair in children. Eur $\mathbf{J}$ Anaesthesiol 2007; 24: 697-701.

40. Ates $Y$, Alanoglu Z, Uysalel A. Use of the laryngeal mask airway during ophthalmic surgery results in stable circulation and few complications: a prospective audit. Acta Anaesthesiol Scand 1998; 42: 1180-3.

41. Treschan TA, Zimmer C, Nass C, Stegen B, Esser J, Peters J. Inspired oxygen fraction of 0.8 does not attenuate postoperative nausea and vomiting after strabismus surgery. Anesthesiology 2005; 103: 6-10.

42. Hamunen K, Vaalamo MO, Maunuksela EL. Does propofol reduce vomiting after strabismus surgery in children? Acta Anaesthesiol Scand 1997; 41: 973-7.

43. Goodarzi M, Matar MM, Shafa M, Townsend JE, Gonzalez I. A prospective randomized blinded study of the effect of intravenous fluid therapy on postoperative nausea and vomiting in 
children undergoing strabismus surgery. Paediatr Anaesth 2006; 16: 49-53.

44. Howard R, Carter B, Curry J, et al. Association of Paediatric Anaesthetists of Great Britain and Ireland. Postoperative pain. Paediatr Anaesth 2008; 18(Suppl 1): 36-63.

45. Chhabra A, Pandey R, Khandelwal M, Subramaniam R, Gupta $S$. Anesthetic techniques and postoperative emesis in pediatric strabismus surgery. Reg Anesth Pain Med 2005; 30: 43-7.

46. Anninger $W$, Forbes B, Quinn G, Schreiner MS. The effect of topical tetracaine eye drops on emergence behavior and pain relief after strabismus surgery. J AAPOS 2007; 11: 273-6.
47. Watson DM. Topical amethocaine in strabismus surgery. Anaesthesia 1991; 446: 368-70.

48. Carden SM, Colville DJ, Davidson AJ, et al. Adjunctive intraoperative local anaesthesia in paediatric strabismus surgery: a randomized controlled trial. Aust N Z J Ophthalmol 1998; 26: 289-97.

49. Kim J, Azavedo L, Bhananker S, Bonn G, Splinter W. Amethocaine or ketorolac eyedrops provide inadequate analgesia in pediatric strabismus surgery. Can J Anesth 2003; 50: 819-23.

50. Apt L, Voo I, Isenberg SJ. A randomized clinical trial of the nonsteroidal eyedrop diclofenac after strabismus surgery. Ophthalmology 1998; 105: 1448-54. 